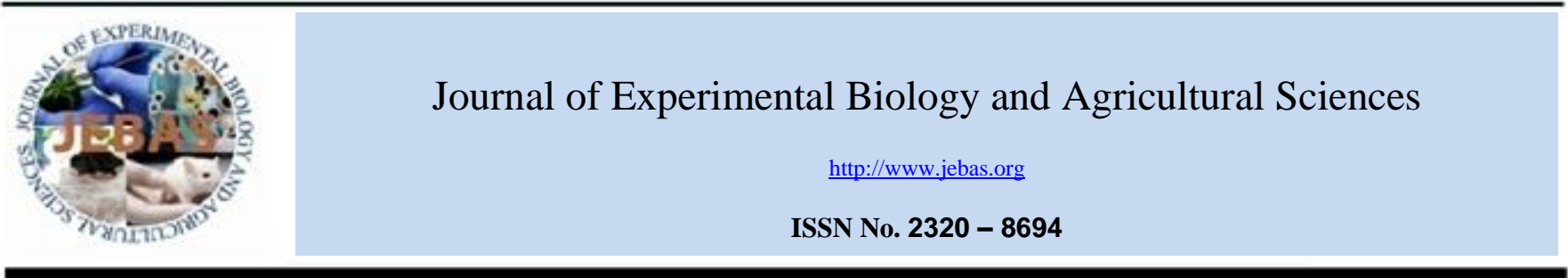

\title{
INHERITANCE OF BLAST DISEASE RESISTANCE IN THE CROSS HUR 3022 X TETEP OF RICE (Oryza sativa L.)
}

\author{
Namrata $^{1}$, R.P. Singh ${ }^{1 *}$, Ramlakhan Verma ${ }^{3}$, Prashant Bisen ${ }^{1}$, Prakash Singh $^{4}$, Basavaraj Teli ${ }^{2}$ \\ ${ }^{1}$ Department of Genetics and Plant Breeding, I. Ag. Sc., Banaras Hindu University, Varanasi- 221005, Uttar Pradesh, India \\ ${ }^{2}$ Department of Mycology and Plant Pathology, I. Ag. Sc., Banaras Hindu University, Varanasi- 221005, Uttar Pradesh, India \\ ${ }^{3}$ Crop Improvement Division, ICAR-NRRI, Cuttack-753006, Odisha, India \\ ${ }^{4}$ Department of Plant Breeding and Genetics, Veer Kunwar Singh College of Agriculture (Bihar Agricultural University, Sabour), Dumraon, Buxar- 802136, Bihar, \\ India
}

Received - September 27, 2019; Revision - November 27, 2019; Accepted -December 19, 2019

Available Online - December 25, 2019

DOI: http://dx.doi.org/10.18006/2019.7(6).529.535

\section{KEYWORDS}

Blast resistance

Disease severity per cent

Inheritance

Polymeric gene action

\begin{abstract}
An experiment was carried out using six generations $\left(\mathrm{P}_{1}, \mathrm{P}_{2}, \mathrm{~F}_{1}, \mathrm{~F}_{2}, \mathrm{~B}_{1}\right.$ and $\left.\mathrm{B}_{2}\right)$ of cross HUR $3022 \mathrm{x}$ Tetep in rice at BHU, Varanasi during year 2017-2018 to know the inheritance pattern of leaf blast disease under artificial inoculation with $L B-T N-2$ isolate of Magnaporthe oryzae in the field condition. The blast disease resistant cultivar 'Tetep' showed $9.32 \%$ disease severity, while high yielding, early maturing susceptible cultivar HUR 3022 showed $43.65 \%$ disease severity against $M$. oryzae. The area under the disease progress curve (AUDPC) of resistance cultivar was observed 127.95 which are significantly less than the susceptible cultivar 605.62. The $F_{1}$ (HUR $3022 \times$ Tetep) plants were observed to be resistant with an average disease severity and AUDPC are $17.54 \%$ and 224.7 , respectively. The $\mathrm{F}_{2}$ population was observed to show three distinct phenotypic classes resistant, moderately resistant and susceptible with a ratio of 9:6:1, respectively. Two backcross Populations, $\mathrm{B}_{1}$ and $\mathrm{B}_{2}$ showed different response from each other during evaluation which results in the phenotypic ratio of $1 \mathrm{R}: 2 \mathrm{MR}: 1 \mathrm{~S}$ in $\mathrm{B}_{1}$ and 1R:0S in $B_{2}$, respectively. The results showed that blast disease resistance occurs in the cross is due to duplicate cumulative effects or polymeric gene effect of two dominant resistant genes i.e., Pil and Pi54.
\end{abstract}

* Corresponding author

E-mail: ravi_piyush@rediffmail.com; singhravi2005@gmail.com (Prof. Ravi Pratap Singh)

Peer review under responsibility of Journal of Experimental Biology and Agricultural Sciences.

Production and Hosting by Horizon Publisher India [HPI] (http://www.horizonpublisherindia.in/).

All rights reserved.
All the articles published by Journal of Experimental Biology and Agricultural Sciences are licensed under a Creative Commons Attribution-NonCommercial 4.0 International License Based on a work at www.jebas.org.

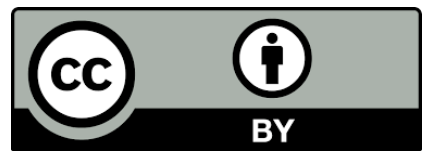




\section{Introduction}

Rice is a staple food crop provides food to more than half of the world's population. Further rice is grown all around the world from as far north Manchuria of China to far south Uruguay and at elevations $>300 \mathrm{~m}$ of Bhutan to $3 \mathrm{~m}$ below sea level in Kerala state of India (Khush, 2005; Khush, 2013). With such diverse growing area, rice is also prone to 70 different types of diseases caused by several biotic agents like fungi, bacteria and viruses along with nematodes causing constitutively $5 \%$ yield loss every year (Song \& Goodman, 2001; Singh et al., 2013a; Arunakumari et al., 2016). Among these diseases, rice blast caused by the fungal pathogen $M$. occurring in more than 85 rice growing countries globally (Scardaci et al., 1997; Gilbert et al., 2004). In India 23 rice growing states possess endemic districts for rice blast so rice production time to time encounter different level of losses due to occurrence of blast (Prasad et al., 2011; Turaidar et al., 2018). During the period 2001-2014, rice leaf blast has emerged as a major constraint in areas of Chhattisgarh, Jharkhand, Tamil Nadu and Uttar Pradesh states (Laha et al., 2011). Although, chemicals can control blast but use of blast-resistant cultivars in rice production is considered an economical and environment friendly disease control strategy. Out of 100 blast resistant genes till identified, several resistance genes have been already introduced into elite rice varieties using Marker Assisted Breeding approaches (Abhilash Kumar et al., 2016; Ellur et al., 2016; Sabin et al., 2016; Usatov et al., 2016; Khan et al., 2018; Kumar et al., 2019; Swathi et al., 2019). Dynamic changes in the race composition of pathogen has often caused breakdown of resistance in most of the improved resistant varieties. Especially cultivars containing a single major resistance gene become susceptible within few years. Stacking of more than one major resistance gene has been proven one of the effective methods to deliver durable resistance against rice blast (Hittalmani et al., 2000; Joshi \& Nayak, 2010; Koide et number of genes into a single cultivar, the knowledge of inheritance pattern of blast disease is prerequisite. Keeping all these fact in view an investigation was carried out using six generations $\left(\mathrm{P}_{1}, \mathrm{P}_{2}, \mathrm{~F}_{1}, \mathrm{~F}_{2}, \mathrm{~B}_{1}\right.$ and $\left.\mathrm{B}_{2}\right)$ in rice to know the inheritance of blast disease under artificial inoculation for blast pathogen in the field condition.

\section{Materials and Methods}

Two indica rice varieties HUR 3022 (Blast susceptible high yielding and early maturing variety) and Tetep (Blast resistant donor variety) were used for staggered sowing at agricultural research farm, Institute of Agricultural Sciences, Banaras Hindu University, Varanasi (Uttar Pradesh) during Kharif 2017 and crossed to produce $F_{1}$ seeds. These $F_{1}$ seeds were planted along with parents at ICAR-National Rice Research Institute, Cuttack oryzae reported as a devastating constraint to rice production al., 2010). For breeding durable rice blast resistance and stacking a

(Odisha) during Rabi 2017-18 to generate seeds of $\mathrm{F}_{1}, \mathrm{~F}_{2}, \mathrm{~B}_{1}\left(\mathrm{~F}_{1} \mathrm{x}\right.$ HUR 3022) and $B_{2}\left(F_{1} \times\right.$ Tetep) generation, which constitutes the study material along with a blast disease check (Co 39) for present investigation. The seedlings of parents (HUR 3022 and Tetep) along with four generations $\left(\mathrm{F}_{1}, \mathrm{~F}_{2}, \mathrm{~B}_{1}\right.$ and $\left.\mathrm{B}_{2}\right)$ and blast disease check (Co 39) were transplanted in the field in a complete family randomized block design with three replications maintaining a spacing of $15 \times 20 \mathrm{~cm}$ plant to plant and row to row, respectively at Agricultural Research Farm, Institute of Agricultural Sciences, Banaras Hindu University, Varanasi (Uttar Pradesh) during Kharif 2018.

The blast infected leaf samples due to $L B-T N-2$ isolate of $M$. Oryzae were obtained from the green house of Department of Mycology and Plant Pathology, Institute of Agricultural Sciences, Banaras Hindu University, Varanasi. Isolation of fungus was carried out under aseptic conditions by spore-drop method following the methodology described in Rajashekara et al. (2017). Isolate was cultured on Potato Dextrose Agar (PDA) and Oat Meal Agar (OMA) medium in petri plates incubated at $28^{\circ} \mathrm{C}$. The morphological identification confirmed the characteristics of pathogen M. oryzae i.e. pyriform to oblong conidia which are hyaline in colour and biseptate measuring $19-27 \times 8-10 \mu \mathrm{m}$ in size (Figure 1b). Disease screening plots were sprayed with 15 days old culture obtained from Oat Meal Agar media (Figure 1a) at a concentration of $1 \times 10^{5}$ conidia/ml and solution also contains Tween-20 $(0.2 \%)$. High humidity in the field was maintained during night by covering the plants with plastic bags to insure development of disease (Figure 1c). The inoculated plants were observed thrice i. e. 7, 14 and 21 days after inoculation (DAI). Disease scoring was performed using 0-9 scale of IRRI-SES scale as described in Table 1 (IRRI, 2013; Singh et al., 2013b).

Table 1 Scale for scoring of rice leaf blast disease (IRRI, 2013; Singh et al., 2013b

\begin{tabular}{|clc|}
\hline Scale & \multicolumn{1}{c|}{ Disease severity } & Host response \\
\hline 0 & Lesion are not present & Resistant (R) \\
\hline 1 & $\begin{array}{l}\text { Small brown specks of pin point size or larger } \\
\text { brown specks without sporulating center }\end{array}$ & Resistant (R) \\
\hline & $\begin{array}{l}\text { Small roundish to slightly elongated, necrotic } \\
\text { gray spots, about 1-2 mm in diameter, with a } \\
\text { distinct brown margin. Lesions are mostly found } \\
\text { on the lower leaves }\end{array}$ & Resistant (R) \\
\hline 3 & $\begin{array}{l}\text { Lesions type is same as in scale 2, but a } \\
\text { significant number of lesions on upper leaf area }\end{array}$ & Resistant (R) \\
\hline 4 & $\begin{array}{l}\text { Typical susceptible blast lesions, 3 mm or longer } \\
\text { infecting less than 4\% of leaf area }\end{array}$ & $\begin{array}{c}\text { Moderately } \\
\text { Resistant (MR) }\end{array}$ \\
\hline 5 & $\begin{array}{l}\text { Typical susceptible blast lesions infecting } \\
\text { 4-10\% of the leaf area }\end{array}$ & $\begin{array}{c}\text { Moderately } \\
\text { Resistant (MR) }\end{array}$ \\
\hline 6 & $\begin{array}{l}\text { Typical susceptible blast lesions infecting } \\
11-25 \% \text { of the leaf area }\end{array}$ & $\begin{array}{c}\text { Moderately } \\
\text { Susceptible (S) }\end{array}$ \\
\hline 7 & $\begin{array}{l}\text { Typical susceptible blast lesions infecting } \\
26-50 \% \text { of the leaf area }\end{array}$ & Susceptible (S) \\
\hline 8 & $\begin{array}{l}\text { Typical susceptible blast lesions infecting 51- } \\
75 \% \text { of the leaf area and many leaves are dead }\end{array}$ & Susceptible (S) \\
\hline 9 & \begin{tabular}{l} 
More than 75\% leaf area affected \\
\hline
\end{tabular} & Susceptible (S) \\
\hline
\end{tabular}

Journal of Experimental Biology and Agricultural Sciences http://www.jebas.org 

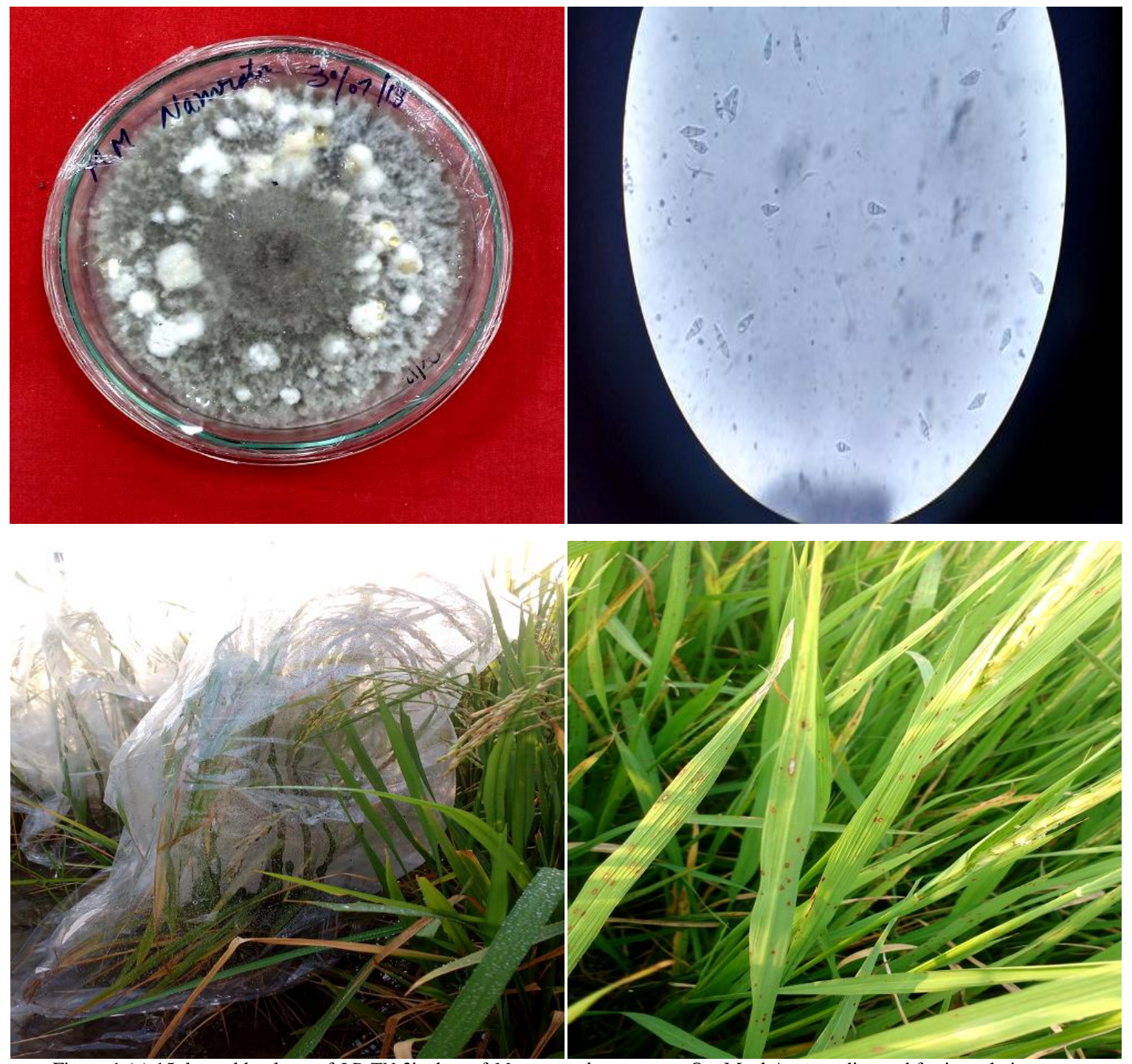

Figure 1 (a) 15 days old culture of $L B-T N$-2isolate of Magnaportheoryzae on Oat Meal Agar media used for inoculation;

(b) Biseptatecharacterstic conidia of Magnaportheoryzaefrom 15 days old culture;

(c) Maintenance of humidity using plastic bags in field;

(d) Symptoms of blast obtained in field after artificial inoculation

The disease severity per cent (DSP) and area under disease progress curve (AUDPC) were calculated according to the formulae described by Sabin et al. (2016). Plants categorized as resistance and susceptible for rice leaf blast based on their disease scores. These observed frequencies were tested using $\chi 2$ test for goodness-of-fit with expected frequencies of resistant and susceptible plants to study the pattern of inheritance of blast resistance in rice.

\section{Results and Discussion}

The donor variety 'Tetep' used in present investigation have shown resistant against $L B-T N-2$ isolate of $M$. oryzae under artificial inoculation in the field condition due to presence of two major dominant resistance genes Pil and Pi54, which showed disease score 1 with 9.32 per cent disease severity. While recipient variety 'HUR 3022' displayed susceptible reaction with disease score 7 and 43.65 per cent disease severity due to absence of these two genes (Table 2). The inaugural symptoms of blast observed on the recipient variety 'HUR 3022' with variable intensities in the form of gray green and water-soaked lesions with a darker green border, which expanded rapidly to several centimeters in length, later resulted into typical diamond shaped lesions (Figure 1d). These results are in agreement with earlier findings for symptoms on susceptible cultivars (Singh et al., 2019). The area under the 
Table 2 Comparison of Disease severity, Area Under Disease Progress Curve (AUDPC) and Lesion number in $\mathrm{P}_{1}, \mathrm{P}_{2}, \mathrm{~F}_{1}, \mathrm{~F}_{2}, \mathrm{~B}_{1}$ and $\mathrm{B}_{2}$ generations of the cross HUR $3022 \times$ Tetep against M. oryzae isolate $L B-T N-2$

\begin{tabular}{|c|c|c|c|c|c|c|c|c|c|c|}
\hline \multirow{2}{*}{ Genotypes } & \multirow{2}{*}{$\begin{array}{l}\text { Plant } \\
\text { scored }\end{array}$} & \multicolumn{3}{|c|}{ Disease Severity (DS \%) } & \multirow{2}{*}{$\begin{array}{c}\text { AUDPC } \\
\text { value }\end{array}$} & \multirow{2}{*}{$\begin{array}{c}\text { Disease } \\
\text { score } \\
\text { (21 DAI) }\end{array}$} & \multirow{2}{*}{$\begin{array}{c}\text { Host } \\
\text { response } \\
\text { (21 DAI) }\end{array}$} & \multirow{2}{*}{$\begin{array}{l}\text { Lesion } \\
\text { number }\end{array}$} & \multirow{2}{*}{$\begin{array}{l}\text { Mean } \\
\text { AUDPC }\end{array}$} & \multirow{2}{*}{$\begin{array}{l}\text { Mear } \\
\text { DS \% }\end{array}$} \\
\hline & & $7 \mathrm{DAI} \pm \mathrm{SD}$ & $14 \mathrm{DAI} \pm \mathrm{SD}$ & $21 \mathrm{DAI} \pm \mathrm{SD}$ & & & & & & \\
\hline Co 39 (C) (30 plants) & 30 & $41.08 \pm 3.87$ & $54.12 \pm 3.79$ & $69.33 \pm 3.06$ & 765.28 & 8 & $\mathrm{~S}$ & 67.38 & 765.29 & 55.26 \\
\hline HUR 3022 (30 plants) & 30 & $28.44 \pm 2.05$ & $42.67 \pm 3.38$ & $59.26 \pm 2.10$ & 605.64 & 7 & $\mathrm{~S}$ & 48.20 & 605.62 & 43.66 \\
\hline Tetep(30 plants) & 30 & $7.22 \pm 1.69$ & $9.34 \pm 2.08$ & $10.66 \pm 2.01$ & 127.96 & 1 & $\mathrm{R}$ & 6.60 & 127.95 & 9.32 \\
\hline$F_{1}$ 's - 30 plants & 30 & $12.65 \pm 1.90$ & $17.37 \pm 2.12$ & $22.52 \pm 2.16$ & 244.69 & 2 & $\mathrm{R}$ & 4 & 224.7 & 17.54 \\
\hline \multirow{3}{*}{$\begin{array}{l}\mathrm{B}_{1}\left(\mathrm{~F}_{1} \times \mathrm{HUR} 3022\right) 60 \\
\text { plants }\end{array}$} & 14 & $11.35 \pm 0.61$ & $18.51 \pm 0.93$ & $26.45 \pm 1.01$ & 323.37 & 3 & $\mathrm{R}$ & \multirow{3}{*}{17.38} & \multirow{3}{*}{464.75} & \multirow{3}{*}{32.86} \\
\hline & 34 & $20.26 \pm 2.35$ & $28.19 \pm 2.03$ & $32.40 \pm 2.62$ & 470.84 & 5 & MR & & & \\
\hline & 12 & $23.70 \pm 3.12$ & $43.63 \pm 3.20$ & $60.04 \pm 3.16$ & 99.53 & 7 & S & & & \\
\hline $\mathrm{B}_{2}\left(\mathrm{~F}_{1} \times\right.$ Tetep $) 60$ plants & 60 & $12.69 \pm 5.70$ & $22.37 \pm 4.89$ & $33.48 \pm 4.44$ & 318.20 & 3 & $\mathrm{R}$ & 17.13 & 318.20 & 22.84 \\
\hline \multirow{3}{*}{$F_{2}{ }^{\prime} s-210$ plants } & 115 & $14.11 \pm 0.47$ & $16.20 \pm 0.55$ & $20.56 \pm 1.03$ & 299.85 & 3 & $\mathrm{R}$ & \multirow{3}{*}{15.95} & \multirow{3}{*}{477.51} & \multirow{3}{*}{34.22} \\
\hline & 84 & $18.78 \pm 5.32$ & $29.86 \pm 4.97$ & $33.47 \pm 5.04$ & 475.9 & 5 & MR & & & \\
\hline & 11 & $39.67 \pm 4.03$ & $41.34 \pm 5.43$ & $65.07 \pm 7.28$ & 655.97 & 7 & $\mathrm{~S}$ & & & \\
\hline
\end{tabular}

SD: Standard deviation, DAI: Days after inoculation, AUDPC: Area under disease progress curve

disease progress curve of resistant donor parent was found 127.95 which is significantly lower than the susceptible recipient parent 605.62. Above results are in accordance with earlier reports of wide difference between area under disease progress curve of resistant and susceptible cultivars (Mahopatra et al., 2008; Nguyen et al., 2015). All the plant of $F_{1}$ generation from the cross HUR $3022 \times$ Tetep were observed as resistant with average disease severity $17.54 \%$ and AUDPC 224.7. These findings are in accordance with earlier reports on resistant response of $F_{1}$ generation in cross of susceptible and resistant cultivars (Gupta et al., 2012).

Two backcross generations, B1 (F1 x HUR 3022) and B2 (F1 x Tetep) of the cross showed different response from each other during evaluation for blast disease resistance. These findings also showed similarity with earlier reports (Persaud et al., 2007; Singh et al., 2014). The plants from $B_{1}$ generation showed three types of responses which included resistant, medium resistant and susceptible response. Average lesion number showed by $\mathrm{B}_{1}$ generation was 17.38 with 464.75 mean AUDPC value and 32.86 per cent disease severity. Out of 60 plants observed in $B_{1}$ generation, 14 plants showed resistant response, 34 plant moderately resistant and 12 plants susceptible response with $\chi 2=$ $1.20, \mathrm{P}>0.05$ indicating that observed data are in agreement with the expected ratio in backcross generation and confirmed modification of mendelian dihybrid ratio of 1:1:1:1 into 1:2:1 ratio Like $B_{1}$, In $B_{2}$ generation also 60 plants observed and all the plants showed resistant response revealed the modification of mendelian dihybrid ratio of 1:1:1:1 into 1:0 ratio. Plants in $\mathrm{B}_{2}$ generation was observed having average lesion number as 17.13, mean AUDPC value as 318.20 and per cent disease severity as 22.84 , respectively (Table 2; Table 3). These results showed that blast disease resistance in two backcross generations was governed by two dominant genes which showed polymeric gene action. Disease resistance governed by two dominant genes in interaction was earlier reported but they reported presence of two independent dominant genes or complementary gene interaction (Persaud et al., 2007; Zewdu et al., 2018).

Plants from $\mathrm{F}_{2}$ generation individually scored and could be categorized into four genotypic classes in a ratio of 9:3:3:1 while three types of phenotypic responses- resistant, moderately resistant and susceptible response were observed during investigation in a ratio of 9:6:1 (Table 2; Table 3). Average lesion numbers in $\mathrm{F}_{2}$ generation were recorded as 15.95 with 477.51 mean AUDPC value and 34.22 per cent disease severity, respectively. In $F_{2}$ generation 210 plants observed which resulted into 115 plants showing resistant response, 84 plants showing moderately resistant response and 11 plants showing susceptible response against blast in a ratio of 9:6:1 with $\chi^{2}=0.70, \mathrm{P}>0.05$ revealed that observed data are in accordance with expected ratio. These results confirmed the modification of mendelian dihybrid ratio 9:3:3:1 into 9:6:1 ratio which was due to presence of two dominant genes showing polymeric gene action or we can say duplicate genes with cumulative effect. These findings are in contradiction with reports of single dominant gene governing blast resistance in rice (Fuji \& Saito, 2007; Sharma et al., 2007; Ashkani et al., 2011). These findings are in partial agreement with the earlier reports of two dominant genes showing interaction for governing blast resistance in rice (Fillip \& Prabhu, 1996; Persaud et al., 2007; Zewdu et al., 2018). 
Table 3 Inheritance of blast resistance in six generations $\mathrm{P}_{1}, \mathrm{P}_{2}, \mathrm{~F}_{1}, \mathrm{~F}_{2}, \mathrm{~B}_{1}$ and $\mathrm{B}_{2}$ generations of the cross HUR $3022 \times$ Tetep against M. oryzae isolate $L B-T N-2$

\begin{tabular}{|c|c|c|c|c|c|c|c|c|c|}
\hline $\begin{array}{l}\text { Parents and } \\
\text { their } \\
\text { populations }\end{array}$ & $\begin{array}{l}\text { Expected gene } \\
\text { combination }\end{array}$ & $\begin{array}{l}\text { Genotypic } \\
\text { frequency }\end{array}$ & $\begin{array}{l}\text { Disease } \\
\text { score at } \\
21 \text { DAI }\end{array}$ & $\begin{array}{l}\text { Disease } \\
\text { reaction } \\
\text { at } 21 \mathrm{DAI}\end{array}$ & $\begin{array}{c}\text { Total no } \\
\text { of plant } \\
\text { observed }\end{array}$ & $\begin{array}{l}\text { Observed } \\
\text { frequencies }\end{array}$ & $\begin{array}{l}\text { Expected } \\
\text { frequencies }\end{array}$ & $\begin{array}{l}\text { Phenotypic } \\
\text { ratio }\end{array}$ & $\begin{array}{c}\chi^{2} \\
\text { value }\end{array}$ \\
\hline HUR 3022 & pilpilpi54pi54 & - & 7 & $\mathrm{~S}$ & 30 & 30 & 30 & - & - \\
\hline Tetep & PilPilPi54Pi54 & - & 1 & $\mathrm{R}$ & 30 & 30 & 30 & - & - \\
\hline $\mathrm{F}_{1}$ & PilpilPi54pi54 & - & 2 & $\mathrm{R}$ & 30 & 30 & 30 & - & - \\
\hline \multirow{4}{*}{$\mathrm{B}_{1}$} & PilpilPi54pi54 & 1 & 3 & $\mathrm{R}$ & \multirow{4}{*}{60} & 14 & 15 & $1 \mathrm{R}$ & \multirow{4}{*}{1.20} \\
\hline & Pilpilpi54pi54 & 1 & \multirow{2}{*}{5} & \multirow{2}{*}{ MR } & & 24 & 30 & PQP & \\
\hline & pilpilPi54pi54 & 1 & & & & דינ & (5) & - & \\
\hline & pilpilpi54pi54 & 1 & 7 & $\mathrm{~S}$ & & 12 & 15 & $1 \mathrm{~S}$ & \\
\hline \multirow{4}{*}{$\mathrm{B}_{2}$} & PilPil Pi54Pi54 & 1 & \multirow{4}{*}{3} & \multirow{4}{*}{$\mathrm{R}$} & \multirow{4}{*}{60} & \multirow{4}{*}{60} & \multirow{4}{*}{60} & \multirow{4}{*}{ 1R:0S } & \multirow{4}{*}{ NA } \\
\hline & PilPi1Pi54pi54 & 1 & & & & & & & \\
\hline & PilpilPi54Pi54 & 1 & & & & & & & \\
\hline & PilpilPi54pi54 & 1 & & & & & & & \\
\hline \multirow{4}{*}{$\mathrm{F}_{2}$} & $P i 1{ }_{1} P i 54_{-}$ & 9 & 3 & $\mathrm{R}$ & \multirow{4}{*}{210} & 115 & 118 & $9 \mathrm{R}$ & \multirow{4}{*}{0.70} \\
\hline & Pi1_pi54pi54 & 3 & \multirow[b]{2}{*}{5} & \multirow{2}{*}{ MR } & & & & & \\
\hline & pilpilPi54_ & 3 & & & & 84 & 79 & $6 \mathrm{MR}$ & \\
\hline & pilpilpi54pi54 & 1 & 7 & $\mathrm{~S}$ & & 11 & 13 & $1 \mathrm{~S}$ & \\
\hline
\end{tabular}

NA: Not applicable

\section{Conclusion}

In any breeding programme related to blast resistance achieving durable broad spectrum blast resistance is a major objective. Results of present investigation revealed that in case of $\mathrm{M}$. oryzae isolate LB-TN-2 infection on populations of cross HUR $3022 \mathrm{x}$ Tetep the resistance to blast is due to presence of two dominant genes showing polymeric gene action or we can say each gene provide resistance when present in dominant state but level of resistance increases when both dominant alleles of the genes present together. Hence it is concluded that to increase the level of blast resistance in a cultivar stacking of multiple resistance genes could be a suitable approach.

\section{Acknowledgement}

We acknowledge Prof. B. K. Sharma, Department of Mycology and Plant Pathology, I. Ag. Sc., BHU, Varanasi (Uttar Pradesh), India for providing lab facilities and pathogen used for blast disease in the experiment. The financial support provided by Ministry of Science and Technology, Department of Science and Technology, New Delhi, Government of India as a DST-INSPIRE Fellowship (INSPIRE Code: IF160896) to first author for full-time doctoral (Ph. D.) degree programme at Banaras Hindu University, Varanasi, Uttar Pradesh, India for the study is gratefully acknowledged.

\section{Conflict of Interest}

The authors declare that there is no conflict of interest.

\section{References}

Arunakumari K, Durgarani CV, Satturu V, Sarikonda KR, Chittoor PDR, Vutukuri B, Laha GS, Nelli APK, Gattu S, Jamal M, Prasadbabu A (2016) Marker-assisted pyramiding of genes conferring resistance against bacterial blight and blast diseases into Indian rice variety MTU1010. Rice Science 23:306-316. 
Ashkani S, Rafii MY, Sariah M, Akmar ASN, Rusli I, Rahim HA, Latif MA (2011) Analysis of simple sequence repeat markers linked with blast disease resistance genes in a segregating population of rice (Oryza sativa). Genetics and Molecular Research 10: 1345-1355.

Ellur RK, Khanna A, Yadav A, Pathania S, Rajashekara H, Singh VK, Gopala Krishnan S, Bhowmick PK, Nagarajan M, Vinod KK, Prakash G, Mondal KK, Singh NK, Vinod Prabhu K, Singh AK (2016) Improvement of basmati rice varieties for resistance to blast and bacterial blight diseases using marker assisted backcross breeding. Plant Science 242: 330-341.

Filippi MC, Prabhu AS (1996) Inheritance of blast resistance in rice to two Pyricularia grisea races, IB-1 and IB-9. Brazilian Journal of Genetics19: 599-604.

Fujii K, Saito YH (2007). Genetics of durable resistance to rice panicle blast derived from an indica rice variety Modan. Japanese Journal of Plant Science, 1: 69-76.

Gilbert MJ, Soanes DM, Talbot NJ (2004) Functional Genomic Analysis of the Rice Blast Fungus Magnaporthe grisea. Applied Mycology and Biotechnology 4: 331-352.

Gupta SK, Sharma R, Rai KN, Thakur RP (2012) Inheritance of foliar blast resistance in pearl millet (Pennisetum glaucum). Plant Breeding 131: 217-219.

Hittalmani S, Parco A, Mew TV, Zeigler RS, Huang N (2000) Fine mapping and DNA marker- assisted pyramiding of the three major genes for blast resistance in rice. Theoretical and Applied Genetics100: 1121-1128.

IRRI (2013) Standardization evaluation system for rice. International Rice Research Institute, P.O. Box 933, 1099 Manila, Philippines 5: 18 .

Joshi RK, Nayak S (2010)Gene pyramiding-A broad spectrum technique for developing durable stress resistance in crops Biotechnology and Molecular Biology Reviews 5: 51-60.

Khan GH, Shikari AB, Vaishnavi R, Najeeb S, Padder BA, Bhat ZA, Parray GA, Bhat MA, Kumar R, Singh NK (2018)Marker-assisted introgression of three dominant blast resistance genes into an aromatic rice cultivar Mushk Budji. Scientific Reports 8:1-13.

Khush GS (2005) What it will take to feed 5.0 billion rice consumers in 2030. Plant Molecular Biology 59: 1-6.

Khush GS (2013) Strategies for increasing the yield potential of cereals: case of rice as an example. Plant Breeding 132: 433-436.
Koide Y, Kawasaki A, Telebanco YM, Hairmansis A, Nguyet N, Bigirimana J, Fujita D, Kobayashi N, Fukuta Y (2010) Development of pyramided lines with two resistance genes, Pish and Pib, for blast disease (Magnaporthe oryzae B. Couch) in rice (Oryza sativa L.). Plant Breeding 129: 670-675.

Kumar SV, Prasad MS, Rambabu R, Madhavi KR, Bhaskar B, Kumar VA, Sundaram RM, Satya AK, Madhav MS, Prakasam V (2019) Marker-Assisted Introgression of Pi-1 Gene Conferring Resistance to Rice Blast Pathogen Pyriculariaoryzae in the Background of Samba Mahsuri. International Journal of Current Microbiology and Applied Sciences 8: 2133-2146.

Abhilash Kumar V, Balachiranjeevi $\mathrm{CH}$, Bhaskar Naik S, Rambabu R, Rekha G, Harika G, Hajira SK, Pranathi K, Anila M, Kousik M, Vijay Kumar S, Yugander A, Aruna J, Dilip Kumar T, Vijaya Sudhakara Rao K, Hari Prasad AS, Madhav MS, Laha GS, Balachandran SM, Prasad MS, Viraktamath BC, Ravindra Babu V, Sundaram RM (2016) Development of gene-pyramid lines of the elite restorer line, RPHR-1005 possessing durable bacterial blight and blast resistance. Frontiers in Plant Science 7: 1-15.

Laha GS, Sailja B, Prasad SM, Ladhalakshmi D, Krishnaveni D, Singh R, Prakasam V, Yugander A, KannanC, Valarmathi P, Ravindra BV (2016) Changes in rice disease scenario in India: An analysis from Production Oriented Survey. Technical Bulletin No.91. ICAR- Indian Institute of Rice Research, Rajendranagar, Hyderabad-500030, Telangana State, India. Pp 95.

Mohapatra NK, Mukherjee AK, Rao AVS, Nayak P (2008) Disease progress curves in the rice blast pathosystem compared with the logistic and gompertz models. ARPN Journal of Agricultural and Biological Science 3: 28-37.

Nguyen TTT, Truong HTH, Nguyen LT, Nguyen LHK (2015) Identification of Rice Blast Resistance Genes in South Central Coast of Vietnam Using Monogenic Lines under Field Condition and Pathogenicity Assays. Journal of Agricultural Science and Technology A and B \& Hue University Journal of Science5: 491-500.

Persaud M, Kumar A, Sengar RBS, Sao A, Dantre RK, Shrivastava (2007) Genetic analysis of blast (PyraculariagriseaSacc.) resistance in Rice (Oryza sativa L.). Journal of Biological Sciences7: 215-217.

Prasad MS, Madhav MS, Laha GS, Lakshmi DL, Krishnaveni D, Mangrauthia SK, Balachandran SM, Sundran RM, Arunakanthi B, Mohan KM, Madhvi KR, Kumar V, Viraktamath BC (2011) (Technical Bulletin No.-57. Directorate of Rice Research (ICAR), Rajendranagar, Hyderabad-500030, A.P., India. pp 52.

Rajashekara H, Prakash G, Pandian RTP, Sarkel S, Dubey A, Sharma P, Chowdary V, Mishra D, Sharma TR, Singh UD 
(2017). An efficient technique for isolation and mass multiplication of $M$. oryzae from blast infected samples. Indian Phytopathology 69:260-265.

Sabin K, Bijay S, Amrit B, Raman GD, Bhuwan S, Priyanka N, Man SS, Prasad GS (2016) Screening of Different Rice Genotypes against (Pyricularia grisea) Sacc. in Natural Epidemic Condition at Seedling Stage in Chitwan, Nepal. Advances in Crop Science and Technology 4: 1-6.

Scardaci SC, Webster RK, Greer CA, Hill JE, William JF, Mutters RG, Brandon DM, McKenzie KS, Oster JJ (1997) Rice blast: A new disease in California. Agronomy Fact Sheet Series. Departement of Agronomy and Range Science, University of California, Davis.

Sharma RC, ShresthaSM, Shrestha, Pandey MP (2007). Inheritance of Blast Resistance and Associated Microsatellite Markers in Rice Cultivar 'Laxmi'. Journal of Phytopathology 155 749-753.

Singh HS, Kaushik SS, Chauhan MS, Negi RS (2019) Efficacy of Different Fungicides against Rice Blast caused by Pyriculariaoryzae (Cav.) under Field Condition in Satna District of Madhya Pradesh. International Journal of Current Microbiology and Applied Sciences8: 63-69.

Singh MK, Singh P, Singh RP, Mohapatra C (2013a) Association Analysis for Yield and Quality Attributes in IndicaRice and Screening of Hybrids Against Blast Disease (MagnaporthegrieseaBarr.). Journal of Plant Sciences 8: 45-56.

Singh P, Singh RP, Singh HB, Singh ON, Samantray S, Singh MK,
Jaiswal HK (2014) Inheritance of Resistance in Indica Rice Cultivar HUR 4-3 against Bacterial Leaf Blight (Xanthomonas oryzaepv. oryzae). International Journal of Agriculture Environment \& Biotechnology37: 255-263.

Singh VK, Singh A, Singh SP, Ellur RK, Singh D, Krishnan SG, Bhowmick PK, Nagarajan M, Vinod KK, Singh UD, Mohapatra T, Prabhu KV, Singh AK (2013b) Marker assisted simultaneous but stepwise backcross breeding for pyramiding blast resistance genes Piz5 and Pi54into an elite basmati rice restorer line 'PRR78'. Plant Breeding132: 486-495.

Song F, Goodman R M (2001) Molecular biology of disease resistance in rice. Physiological and Molecular Plant Pathology 59: $1-11$.

Swathi G, Rani CVD, Jamaloddin M, Madhav MS, Vanisree S, Anuradha C, Kumar NR, Arun Prem Kumar N, Aruna Kumari K, Sri Chandana Bhogadhi, Ramprasad E, Sravanthi P, . Krishnam Raju S, Bhuvaneswari, Rajan CPD, Jagadeeswar R (2019) Markerassisted introgression of the major bacterial blight resistance genes, $X a 21$ and $x a 13$, and blast resistance gene, Pi54, into the popular rice variety, JGL1798. Molecular Breeding 39: 58.

Turaidar V, Reddy M, Anantapur R, Krupa KN, Dalawai N, Deepak CA, Kumar KMH (2018) Screening of traditional rice varieties (TRVs) for blast resistance. Journal of Pharmacognosy and Phytochemistry, 7: 1384-1388.

Usatov AV, Kostylev PI, Azarin KV, Markin NV, Makarenko MS, KhachumovVA, Bibov M Y (2016) Introgression of the rice blast resistance genes Pi1, Pi2 and Pi33 into Russian rice varieties by marker-assisted selection. Indian Journal of Genetics 76: 18-23. 